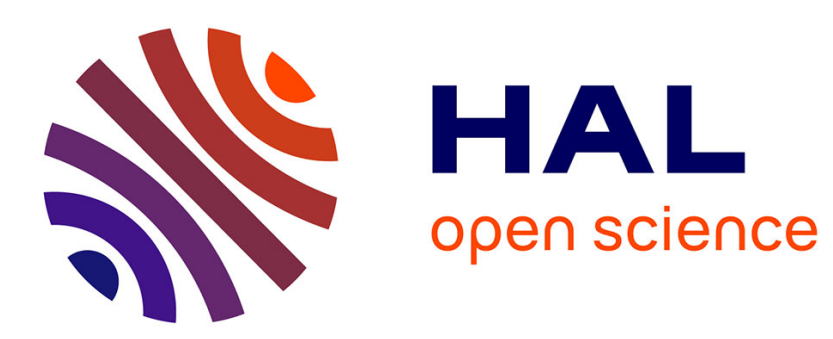

\title{
Immobilization of Olfactory Receptors Carried by Nanosomes onto a Gold Sensor Surface
}

\author{
Jasmina Vidic, Yanxia Hou
}

\section{To cite this version:}

Jasmina Vidic, Yanxia Hou. Immobilization of Olfactory Receptors Carried by Nanosomes onto a Gold Sensor Surface. G Protein-Coupled Receptor Screening Assays. Methods and protocols, pp.8595, 2021, Methods in Molecular Biology, 10.1007/978-1-0716-1221-7_6 . hal-03340365

\section{HAL Id: hal-03340365 https://hal.science/hal-03340365}

Submitted on 13 Oct 2021

HAL is a multi-disciplinary open access archive for the deposit and dissemination of scientific research documents, whether they are published or not. The documents may come from teaching and research institutions in France or abroad, or from public or private research centers.
L'archive ouverte pluridisciplinaire HAL, est destinée au dépôt et à la diffusion de documents scientifiques de niveau recherche, publiés ou non, émanant des établissements d'enseignement et de recherche français ou étrangers, des laboratoires publics ou privés. 


\section{Chapter 6}

\section{Immobilization of Olfactory Receptors Carried by Nanosomes onto a Gold Sensor Surface}

Jasmina Vidic ${ }^{1}$ and Yanxia $\mathrm{Hou}^{2}$

${ }^{1}$ INRAE, AgroParisTech, Micalis Institute, Université Paris-Saclay, 78350 Jouy-en-Josas, France.

${ }^{2}$ University Grenoble Alpes, CEA, CNRS, IRIG-SyMMES, 17 Rue des Martyrs, 38000 Grenoble, France.

Email : jasmina.vidic@inrae.fr yanxia.hou-broutin@cea.fr 
Chapter 6

\title{
Immobilization of Olfactory Receptors Carried by Nanosomes onto a Gold Sensor Surface
}

\author{
Jasmina Vidic and Yanxia Hou
}

\begin{abstract}
Mammalian olfactory receptors (ORs) constitute the largest family of G-protein coupled receptors, with up to about 1000 different genes per species, each having specific odorant ligands. ORs could be used as sensing elements of highly specific and sensitive bioelectronic hybrid devices such as bioelectronic noses. After optimized immobilization onto the device, natural ORs provide molecular recognition of various odors with their intrinsic sensitivity, discrimination, and detection properties. However, the main difficulties are related to the low expression level of recombinant ORs, their stability and potential loss of activity. Such drawbacks can be successfully overcome in bioelectronic noses integrating nanosomes (nanometric membrane vesicles carrying ORs) that are stably immobilized through a specific antibody. The advantages of such a platform rely on the fact that ORs stay in the natural membrane environment and thus, preserve their full activity. Thanks to their small sizes, nanosomes offer potential for micro- and nano-scale sensor development. In this paper, we summarize the key elements regarding nanosomes production and manipulation and provide an example of their immobilization onto a gold sensor surface. Rat ORI7 is used as representative OR that can be functionally expressed in Saccharomyces cerevisiae. The receptor was not purified but only nanosomes were prepared. Nanosomes were immobilized onto functionalized gold surface using the anti-I7 antibody. Utilization of the antibody provides enrichment of ORI7 on the sensor surface but also uniform and appropriate orientation of the receptors. These features are crucial in optimization of bioelectronic nose' analytical performances.
\end{abstract}

Key words G-protein coupled receptors, Olfactory receptors, Nanosomes, Bioelectronic noses, Immobilization, Gold surface

\section{Introduction}

Olfaction is a chemical sense that is essential for the mammals. Various odor molecules in the environment are detected by olfactory receptors (ORs) with exquisite sensitivity [1]. ORs belong to the G-protein coupled receptors (GPCRs) superfamily that all share a seven transmembrane domains topology [1-3]. They are mainly expressed in the membrane of 
olfactory sensory neurons in the olfactory epithelium that covers the caudal and upper part of the nasal cavity. ORs can discriminate between their odorant ligand and similar molecules with slight difference in functional groups, molecular size or shape. Upon odorant molecule binding to an OR, the conformation of the receptor changes. Such a change triggers the signaling cascade transmission in the olfactory sensory neuron that is conducted to the olfactory bulb, and, further to the cortical structures for odor identification. The binding of odorant molecules to ORs is the first event in the perception and discrimination of thousands of different odorants from the external environment.

The intrinsically high sensitivity and selectivity of the animal ORs to detect and discriminate odorant molecules make them very promising as recognition elements in the development of novel analytical tools such as bioelectronic noses. Such bioelectronic hybrid devices with good odor detection performances can be obtained through two main achievements: (i) the reproducible preparation of functional OR sample, and (ii) the appropriate immobilization of OR onto a solid sensor surface with maintained recognition activity.

We previously demonstrated the feasibility of bioelectronic noses using the rat I7 OR and human OR1740 [4-14]. To obtain a sufficient amount of the receptor, the ORs were functionally expressed in the budding yeast Saccharomyces cerevisiae $[15,16]$. For instance, rat olfactory receptor ORI7 (ORL11 in Olfactory data base, OrDB) was heterologously expressed in the yeast $S$. cerevisiaeas strain MC18 as previously described [15]. For this, yeast cells were transformed with pJH2-I7 plasmid that carries a galactose inducible GAL1/10 promoter [15]. Other yeast expression plasmids are commercially available. The pJH2-I7 plasmid enables expression of ORs with a cmyc tag fused at its N-terminus and a HA tag at its C-terminus $[15,16,13]$. Tags enable to orientate receptor molecules on the sensor surface by using the specific anti-cmyc or anti-HA antibodies. Alternatively, in case when a specific antibody against the OR of interest exists, it can be used for immobilization purposes.

a)

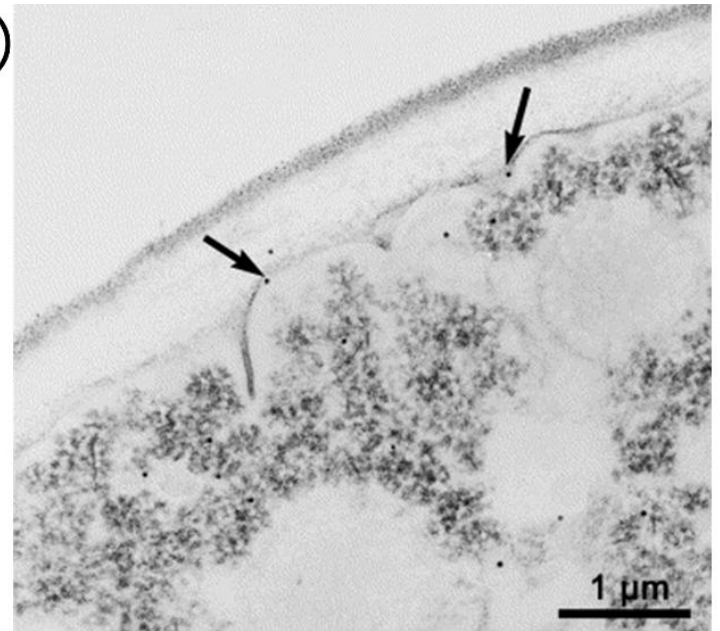

b)

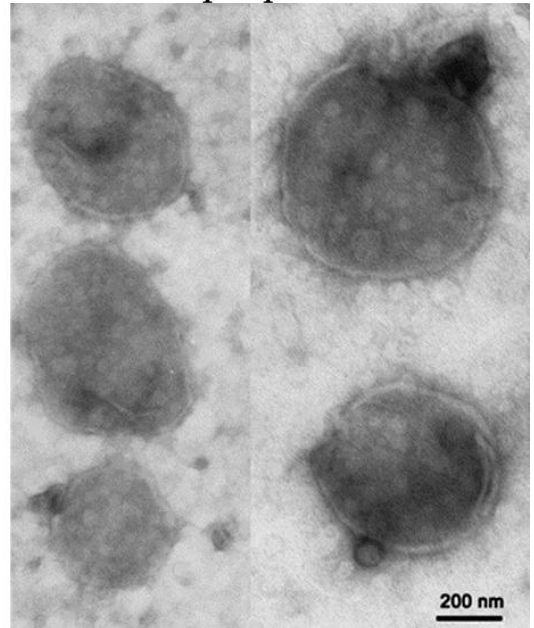

Fig. 1 TEM visualization of a yeast cell expressing ORI7 and its membrane fraction. (a) Receptors were immuno-labeled using the primary anti-I7 antibody and the $10 \mathrm{~nm}$ gold-conjugated secondary antibody. Arrows show gold grains present on the plasma membrane, which indicate ORI7

localization at the plasma membrane. (b) Yeast membrane fraction obtained after cell mechanical disruption and ultracentrifugation in the form of vesicles. (Reproduced from ref. [4] with permission from Elsevier)

We successfully demonstrated that olfactory receptors with their seven transmembrane domains conformation localized in the yeast plasma membrane and conserved their odorant recognition activities $[4,15]$. Commonly, a high-level expression of an OR in yeast leads to 
accumulation of the receptor within the cell. However, we showed that inducting receptor expression at $15{ }^{\circ} \mathrm{C}$, yields lower expression level but produced receptor molecules are properly addressed to the plasma membrane [4,12,14,15]. Fig. 1a shows the ultrastructural visualization of immunogold labeling of OR I7 that confirms adequate receptor cell localization. To preserve OR functional conformation out of the cell, we developed a procedure to prepare membrane lipidic vesicles carrying ORs. These membrane structures, so-called 'nanosomes' because of their nanometric diameter, stabilize receptor conformation and thereby fully preserve their recognition properties [17-20,4,9]. Fig. 1b shows membrane vesicles visualized by the transmission electronic microscopy. Next, we elaborated an efficient immobilization of nanosomes onto a gold sensor surface using a specific antibody $[6,7,13]$. Our approach allowed for the development of original bioelectronic noses with good sensitivity and selectivity, which are promising for various applications. Finally, it is noteworthy that the same strategy can be applied for other GPCRs [21,22].

\section{Materials}

Prepare all solutions using ultrapure water (18.2 M $\mathrm{M}-\mathrm{cm}$ resistivity, prepared by purifying deionized water) and analytical grade reagents (see Note 1). Prepare and store all solutions at $4^{\circ} \mathrm{C}$ (unless indicated otherwise). Meticulously follow all waste disposal regulations when disposing waste materials.

\subsection{Isolation of Membrane fraction}

1. Phenylmethylsulfonyl fluoride (PMSF) stock solution: $1 \mathrm{M}$. Weigh $0.174 \mathrm{~g}$ of PMSF using a high precision balance and transfer it to a $1.5 \mathrm{~mL}$ plastic tube. Add $1 \mathrm{~mL}$ of ethanol to the tube and vortex (see Note 2).

2. Glass beads (425-600 $\mu \mathrm{m}$, Sigma).

3. Complete ${ }^{\mathrm{TM}}$ Protease Inhibitor Cocktail (Roche), 1 tablet for $50 \mathrm{~mL}$.

4. Complete Supplement Mixture synthetic drop-out (CSM) media without HIS, LEU, TRP, URA (Bio101, Inc., Vista, CA, USA).

5. Lysis buffer: $50 \mathrm{mM}$ Tris- $\mathrm{HCl}, \mathrm{pH} 8.8,1 \mathrm{mM}$ EDTA, $0.1 \mathrm{mM}$ PMSF, $250 \mathrm{mM}$ sorbitol and Complete $^{\mathrm{TM}}$ Protease Inhibitor Cocktail. Add $100 \mathrm{~mL}$ water to a $1 \mathrm{~L}$ graduated cylinder or a glass beaker (see Note 3). Weigh separately: $6.057 \mathrm{~g}$ of Tris-HCl, $0.292 \mathrm{~g}$ of EDTA and $45.54 \mathrm{~g}$ of sorbitol and transfer them all to the cylinder or the beaker.

6. Add a magnetic flea and place the cylinder or the beaker on a magnetic stirring plate to mix the solution. Adjust $\mathrm{pH}$ with $\mathrm{HCl}$ (see Note 4). Make up to $1 \mathrm{~L}$ with water. Just before use, take $100 \mathrm{~mL}$ of this buffer solution and add $10 \mu \mathrm{L}$ of $1 \mathrm{M}$ PMSF stock solution and 2 tablets of complete protease inhibitor cocktail.

7. Yeast growing medium: 10X stock solution. Suspend $6.8 \mathrm{~g}$ of yeast nitrogen base without amino acids (Difco, Detroit, MI, USA), $5 \mathrm{~g}$ of CSM powder and $5.4 \mathrm{~g}$ adenine in $100 \mathrm{~mL}$ of ultrapure water. Filter-sterilize this $10 \mathrm{X}$ stock solution and store at $2-8{ }^{\circ} \mathrm{C}$.

8. Yeast growing medium: $1 \mathrm{X}$. Right before utilization, aseptically pipette $25 \mathrm{~mL}$ of the yeast growing medium 10X stock solution into $225 \mathrm{~mL}$ ultrapure water into a $1 \mathrm{~L}$ Erlenmeyer. Mix thoroughly by shaking (see Note 5).

9. Phosphate buffered saline (PBS) tablet (Sigma-Aldrich). Prepare 1X PBS.

10. PBS-glycerol solution: $10 \%$. Add $10 \mathrm{~mL}$ of pure glycerol to $90 \mathrm{~mL}$ PBS.

11. Ultrasonic Bath (see Note 6). 
12. Dounce homogenizer.

13. Pierce ${ }^{\mathrm{TM}}$ BCA Protein Assay Reagent (Fisher Scientific).

14. Saccharomyces cerevisiae yeast cells transformed with $\mathrm{pJH2}$-I7 plasmid that carries a galactose inducible GAL1/10 promoter (see Note 7). Just before inoculation defreeze slowly an aliquot.

15. UV-vis spectrophotometer (see Note 8).

16. Centrifugation tubes of $250 \mathrm{~mL}$ and $50 \mathrm{~mL}$.

\subsection{Immobilization}

1. Thiol 1 stock solution: $10 \mathrm{mM}$. Thiol 1: N-(2-\{2-[2-(2-\{2-[2-(1-mercaptoundec-11-yloxy)ethoxy]-ethoxy\}-ethoxy)-ethoxy]-ethoxy\}-ethyl) biotinamide (HS-C11-EG6-Biotin, ProChimia Surfaces, Poland). Add $1 \mathrm{~mL}$ absolute ethanol to a $2 \mathrm{~mL}$ glass vial with a cap.

2. Weigh $6.94 \mathrm{mg}$ thiol 1 using a high precision balance and transfer to the vial. Mix the solution. Close the cap. (see Note 9 ).

3. Thiol 2 stock solution: $100 \mathrm{mM}$. Thiol 2: 2-\{2-[2-(2-\{2-[2-(1-mercaptoundec-11-yloxy)-ethoxy]ethoxy\}-ethoxy)-ethoxy]-ethoxy] - ethanol (HS-C11-EG6, ProChimia Surfaces, Poland). Add $1 \mathrm{~mL}$ absolute ethanol to a $2 \mathrm{~mL}$ glass vial with a cap. Weigh $46.9 \mathrm{mg}$ thiol 2 using a high precision balance and transfer to the vial. Mix the solution. Close the cap. (see Note 9 ).

4. Mixed thiol solution: $0.1 \mathrm{mM}$ thiol 1 and $1 \mathrm{mM}$ thiol 2. Add $1 \mathrm{~mL}$ absolute ethanol to a clean $10 \mathrm{~mL}$ glass beaker. Add $50 \mu \mathrm{L}$ thiol 1 stock solution. Add $50 \mu \mathrm{L}$ thiol 2 stock solution. Add $3.45 \mathrm{~mL}$ absolute ethanol to obtain the final volume of $5 \mathrm{~mL}$. Mix the solution.

5. Phosphate buffered saline (PBS): $0.01 \mathrm{M}$ phosphate buffer, $0.0027 \mathrm{M}$ potassium chloride and $0.137 \mathrm{M}$ sodium chloride, $\mathrm{pH} 7.4$, at $25^{\circ} \mathrm{C}$. Add $200 \mathrm{~mL}$ ultrapure water to a $250 \mathrm{~mL}$ glass beaker.

6. Add one PBS tablet (Sigma-Aldrich) in the beaker. Stir until the complete dissolution of the tablet.

7. Neutravidin stock solution: $0.1 \mathrm{mM}$. Weigh $6 \mathrm{mg}$ neutravidin (Pierce, Thermo Fisher Scientific) using a high precision balance and transfer to a $1.5 \mathrm{~mL}$ Eppendorf. Add $1 \mathrm{~mL}$ PBS. Mix the solution with a Vortex-Mixer. Store at $-20^{\circ} \mathrm{C}$.

8. Rabbit anti-I7 polyclonal antibody raised against its N-terminal 15 aminoacids was custommade by Neosystem (Strasbourg, France). The antibody was biotinylated using a DSB- $\mathrm{X}^{\mathrm{TM}}$ Biotin Protein Labeling kit (Molecular Probes, Leiden, Netherlands).

9. Biotinylated rabbit anti-I7 polyclonal antibody (Biot-anti-I7-Ab) stock solution: $0.1 \mathrm{mM}$. Weigh $15 \mathrm{mg}$ Biot-anti-I7-Ab using a high precision balance and transfer to a $1.5 \mathrm{~mL}$ Eppendorf. Add $1 \mathrm{~mL}$ PBS. Mix the solution with a Vortex-Mixer. Store at $-20^{\circ} \mathrm{C}$.

10. Solution of nanosomes $(0.1 \mathrm{mg} / \mathrm{mL})$ containing OR I7 in PBS (details given later).

\section{Methods}

Carry out all procedures at room temperature unless otherwise specified.

\subsection{Preparation of membrane} fraction carrying ORI7

1. Put $250 \mathrm{~mL}$ of yeast growing medium $1 \mathrm{X}$ (see Note 5) in $1 \mathrm{~L}$ Erlenmeyer. Add sterilely $5 \mathrm{~g}$ glucose to the solution.

2. Add $50 \mu \mathrm{L}$ of transformed S. cerevisiae to the medium (see Note 7) to inoculate the medium very lightly. Incubate the solution at $30^{\circ} \mathrm{C}$ under $180 \mathrm{rpm}$ shaking until yeast reaches the exponential growth phase (see Note 8). It usually takes $24 \mathrm{~h}$. 
3. Collect and transfer the yeast suspension into a $250 \mathrm{~mL}$ centrifugation tube. Spin at 2,500 x g, for $20 \mathrm{~min}$ at $4{ }^{\circ} \mathrm{C}$. Remove supernatant by decanting and resuspend pellet in $250 \mathrm{~mL}$ of yeast growing medium $1 \mathrm{X}$ in an $1 \mathrm{~L}$ Erlenmeyer.

4. Add $5 \mathrm{~g}$ of galactose to induce ORI7 expression. Incubate solution at $15^{\circ} \mathrm{C}$ under shaking (180 rpm) for $60 \mathrm{~h}$ (see Note 10).

5. Collect the solution and transfer it into $250 \mathrm{~mL}$ centrifugation tubes. Spin at 2,500 x g, for 20 $\min$ at $4{ }^{\circ} \mathrm{C}$.

6. Remove supernatant by decanting and resuspend pellet in $50 \mathrm{~mL}$ of ice-cold water. Transfer the suspension into a $50 \mathrm{~mL}$ centrifugation tube.

7. Vortex tube. Spin at $2,500 \times \mathrm{g}$, for $20 \mathrm{~min}$ at $4{ }^{\circ} \mathrm{C}$. Repeat this procedure to wash twice yeast cells with ice-cold water.

8. Spin at $2,500 \times \mathrm{g}$, for $20 \mathrm{~min}$ at $4{ }^{\circ} \mathrm{C}$ to harvest cells by centrifugation.

9. Resuspend washed cells in $1 \mathrm{~mL}$ of ice-cold lysis buffer. Transfer the solution to a $2 \mathrm{~mL}$ plastic tube.

10. Add glass beads to the resuspended yeast cells to obtain a total volume of about $1.5 \mathrm{~mL}$.

11. Disturb cells by seven cycles of $1 \mathrm{~min}$ of vigorous vortexing / $1 \mathrm{~min}$ of cooling on ice.

12. Leave beads to precipitate and pool supernatant by pipetting.

13. Centrifuge supernatant at $5000 \mathrm{~g}$ for $10 \mathrm{~min}$ at $4^{\circ} \mathrm{C}$ to remove by precipitation unbroken cells and cell walls.

14. Pooled the second supernatant and ultra-centrifuge it at $40,000 \mathrm{~g}$ for $40 \mathrm{~min}$ at $4^{\circ} \mathrm{C}$.

15. Discharge supernatant containing cytosolic fraction. Keep pallet containing membrane fraction.

\subsection{Nanosomes preparation}

1. Add $200 \mu \mathrm{L}$ PBS-glycerol solution to the cell pallet enriched in membranes.

2. Resuspend it manually using a Dounce homogenizer. This step allows to obtain small membrane vesicles of different sizes (see Note 11), that are named microsomes.

3. Determine the total protein concentration in the membrane fraction using the Pierce ${ }^{\mathrm{TM}} \mathrm{BCA}$ Protein Assay Reagent kit. Usually total protein concentration is in the range between $5-15$ $\mathrm{mg} / \mathrm{mL}$.

4. Immediately before use, sonicate $200 \mu \mathrm{L}$ of the membrane fraction using ultrasonic bath in ice-cold water for $20 \mathrm{~min}$ at $120 \mathrm{~W}, 42 \mathrm{kHz}$ (see Note 12) to obtain nanosomes of uniform diameters of about $50 \mathrm{~nm}$ ( see ref. 14 ).

5. Dilute nanosome preparation to $0.1 \mathrm{mg} / \mathrm{mL}$ using PBS of total proteins for immobilization purposes. $5 \mathrm{~mL}$ of $0.1 \mathrm{mg} / \mathrm{mL}$ nanosome soluton is used in each immobilization procedure.

\subsection{Immobilization of ORs onto the gold sensor surface}

1. Treat the gold surface by plasma, generated at 0.6 mbar with $75 \%$ Oxygen and $25 \%$ Argon, with a power of $40 \mathrm{~W}$ for $3 \mathrm{~min}$, using the Femto plasma cleaner (Diener Electronic, Germany) to remove organic contaminants.

2. Immerse the gold solid substrate into $5 \mathrm{~mL}$ mixed thiol solution in the glass beaker. Cover the beaker with Parafilm to avoid solvent evaporation (see Note 5). Fig. 2 shows chemical structures of the used thiols.

3. Leave the gold substrate in the solution for $18 \mathrm{~h}$ at room temperature, for the functionalization of the surface by the formation of mixed self-assembled monolayer.

4. Take out the functionalized gold substrate with a tweezer. Immerse it into $5 \mathrm{~mL}$ ethanol in a new and clean beaker for 5 min for rinsing. 
5. Repeat the step 4 two more times.

6. Take out the gold substrate with the tweezer. Dry the gold surface under nitrogen flow.

7. Add $4995 \mu \mathrm{L}$ PBS in a new and clean beaker. Inject $5 \mu \mathrm{L}$ neutravidin stock solution. Mix gently the solution.

8. Put the gold substrate into the neutravidin solution in the glass beaker. Leave for $90 \mathrm{~min}$.

9. Immerse the gold substrate into $5 \mathrm{~mL}$ PBS in a new and clean beaker for $5 \mathrm{~min}$ for rinsing.

10. Repeat the step 9 two more times.

11. Take out the gold substrate with the tweezer. Dry the gold surface under nitrogen flow.

12. Add $4995 \mu \mathrm{L}$ PBS in a new and clean beaker. Inject $5 \mu \mathrm{L}$ Biot-anti-I7-Ab stock solution. Mix gently the solution.

13. Put the gold substrate into Biot-anti-I7-Ab solution in the glass beaker. Leave for $1 \mathrm{~h}$.

14. Immerse the gold substrate into $5 \mathrm{~mL}$ PBS in a new and clean beaker for $5 \mathrm{~min}$ for rinsing.

15. Repeat the step 14 two more times.

16. Take out the gold substrate with the tweezer. Dry the gold surface under nitrogen flow.

17. Immerse the gold substrate into $5 \mathrm{~mL}$ of $0.1 \mathrm{mg} / \mathrm{mL}$ nanosome soluton in the glass beaker. Incubate for $1 \mathrm{~h}$.

18. Take out the gold substrate with the tweezer. Immerse it into $5 \mathrm{~mL}$ PBS in a new and clean beaker for $5 \mathrm{~min}$ for rinsing.

19. Repeat the step 16 two more times.

20. Put the gold substrate in $5 \mathrm{~mL}$ PBS in a new and clean beaker. Cover the beaker with Parafilm. Store at $4^{\circ} \mathrm{C}$. Fig 3. Illustrates the whole immobilization strategy.

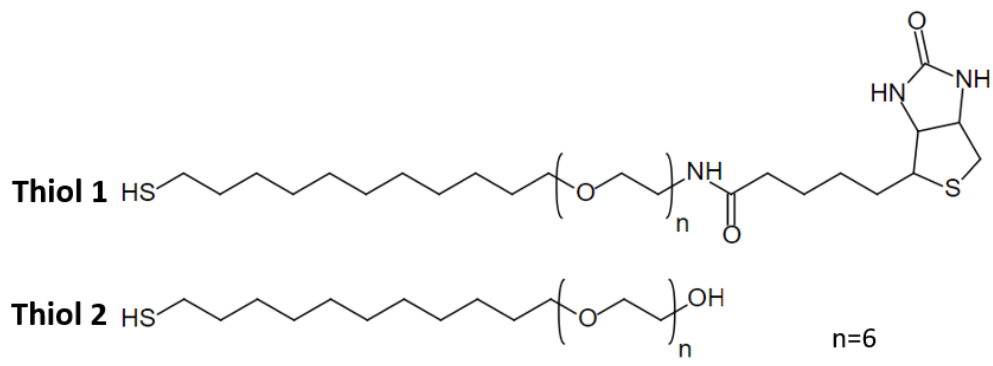

Fig. 2 Chemical structures of the thiol 1 and thiol 2

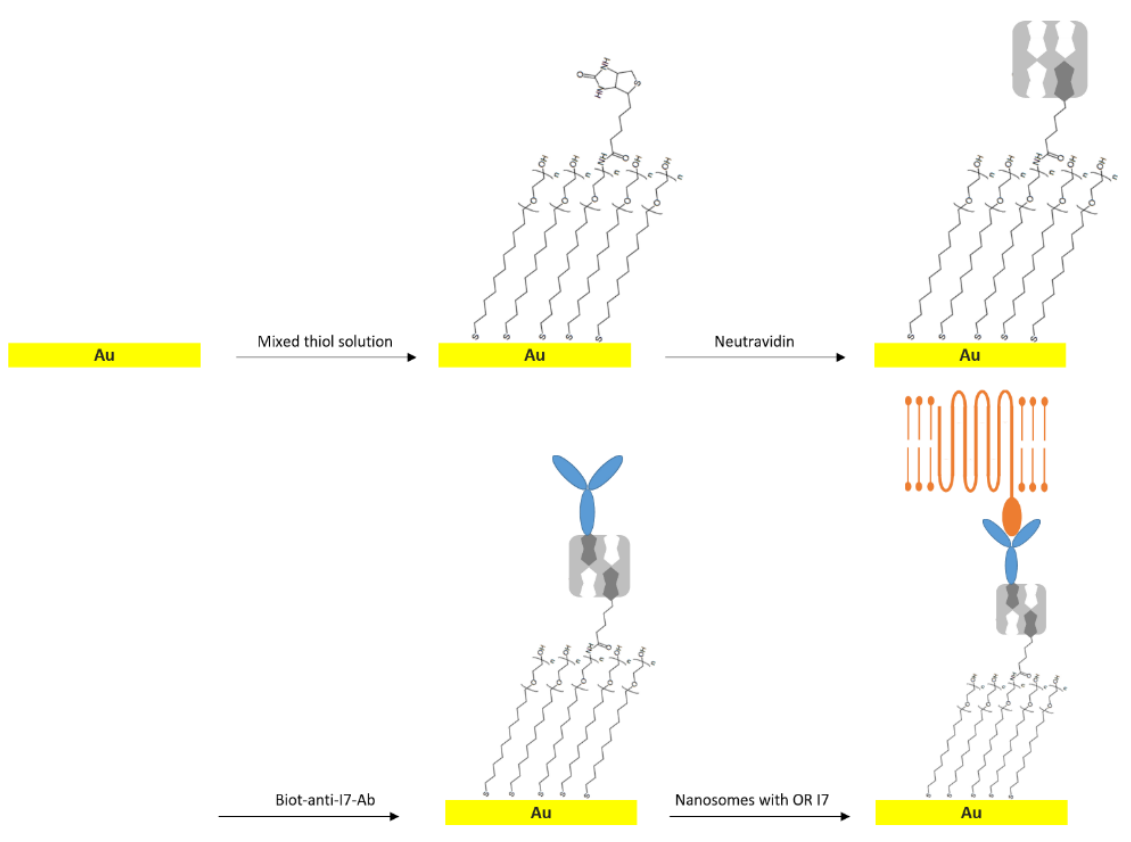




\section{Notes}

1. Wear a protective glasses and gloves.

2. Work in the fume hood when manipulate PMSF. PMSF is a serine protease inhibitor that is commonly used when cell lysate are prepared as it prevents protein degradation. However, it cannot inhibit all serine proteases. PMSF is very instable in water solutions. Its half-life is only $35 \mathrm{~min}$ at $\mathrm{pH} 8$ at $25^{\circ} \mathrm{C}$. Stock solutions in ethanol are more stable for at least $24 \mathrm{~h}$.

3. Having water at the bottom of the cylinder allows the magnetic stir bar to turn immediately, which helps to dissolve the Tris.

4. At the beginning, concentrated $\mathrm{HCl}$ can be used to get closer to the required $\mathrm{pH}$. Then, it would be better to use $\mathrm{HCl}$ with lower concentration. When close to the required $\mathrm{pH}$, slowly add $\mathrm{HCl}$ solution using a Pasteur pipette, not to add too much at a time, since the $\mathrm{pH}$ will change rapidly.

5. Yeast cells and medium should be kept in aseptic conditions to avoid any contamination from foreign bacteria inherent in the environment (like airborne microorganisms or microbes from the lab bench-top or other surfaces). Equipment (Erlenmeyer, glassware, Petri etc.) has to be sterilized because potential contamination may interfere with the results. Manipulations can be performed near the Bensen burner. The burner has two adjustments: the first is the knob underneath which adjusts the amount of gas going into the burner tube, and the second is the barrel of the burner, which enables to adjust the amount of air going into the burner. Both air and gas should be adjust to a minimal open position before lighting a Bunsen burner. After lighting the air and gas should be adjusted to provide a hissing, small, blue flame within a taller lighter blue/violet flame.

6. Use ear protection because ultrasonic baths create audible sound.

7. Transformed yeast can be stored at $-80^{\circ} \mathrm{C}$ until OR-nanosome production. For this, $10 \%-50$ $\%(\mathrm{v} / \mathrm{v})$ of sterile glycerol is added into yeast culture at exponential growing phase (optical density of 0.4 to 1 at $600 \mathrm{~nm}$ ) and aliquots within $2 \mathrm{~mL}$ plastic vials are frozen at $-80^{\circ} \mathrm{C}$. Before utilization, one aliquot is allowed to defreeze slowly. The plastic vial should be open in aseptic conditions to avoid any contamination from foreign bacteria and fungi inherent in the environment.

8. Exponential growing phase of yeast cells can be determined by measuring absorbance at 600 $\mathrm{mn}$. Because absorbance unit is arbitrary, its value depends on the spectrophotometer used. The yeast growing kinetic is usually flowed before performing membrane fraction preparation. In our case exponential phase corresponded to absorbance between 0.4 and 1 .

9. Work in the fume hood when manipulate thiols and thiol solutions.

10. Various temperatures were used during induction of transformed yeast and the production of ORs was checked. A low temperature of $15^{\circ} \mathrm{C}$ was shown to help receptors to be correctly addressed to the yeast plasma membrane with a preserve natural seven transmembrane conformation.

11. Resuspended pallet contains membrane fraction in a form of microsomes with diameters ranging from 40 to $700 \mathrm{~nm}$. Membrane fraction can be prepared in large amounts, aliquot and stored in aliquots at $-80{ }^{\circ} \mathrm{C}$ frozen and stored at $-80{ }^{\circ} \mathrm{C}$ for many weeks without losing biological activity.

12. Preparation is sonicated for $20 \mathrm{~min}$ at $120 \mathrm{~W}, 42 \mathrm{kHz}$. If ultrasonic bath has low power/frequency characteristic time of sonication should be increased. During prolonged sonication, ice has to be added to ensure cold environment. 


\section{Acknowledgment}

This work was financially supported by the SPOT-NOSED Project of the European Community (IST-2001-38739).

\section{References}

1. Buck L, Axel R (1991) A novel multigene family may encode odorant receptors: a molecular basis for odor recognition. Cell 65 (1):175-187. doi: 10.1016/0092-8674(91)90418-x.

2. Firestein $S$ (2001) How the olfactory system makes sense of scents. Nature 413 (6852):211-218. doi: $10.1038 / 35093026$.

3. Persaud K, Dodd G (1982) Analysis of discrimination mechanisms in the mammalian olfactory system using a model nose. Nature 299 (5881):352-355. doi: 10.1038/299352a0.

4. Gomila G, Casuso I, Errachid A, Ruiz O, Pajot E, Minic J, Gorojankina T, Persuy M, Aioun J, Salesse R (2006) Advances in the production, immobilization, and electrical characterization of olfactory receptors for olfactory nanobiosensor development. Sensors and Actuators B: Chemical 116 (1-2):66-71. doi.org/10.1016/j.snb.2005.11.083.

5. Gomila G, Errachid A, Bessueille F, Ruiz O, Pajot E, Minic J, Gorojankina T, Salesse R, Villanueva G, Bausells J Artificial nose integrating biological olfactory receptors and NEMS. In: International Symposium on Olfaction and Electronic Nose (ISOEN), 2005. vol CONF. pp 529532. doi: 10.1109/SCED.2005.1504506.

6. Wade F, Espagne A, Persuy M, Vidic J, Monnerie R, Merola F, Pajot-Augy E, Sanz G Relationship between homo-oligomerization of a mammalian olfactory receptor and its activation state demonstrated by bioluminescence resonance energy transfer. Journal of Biological Chemistry, 286:15252-15259. doi: 10.1074/jbc.M110.184580.

7. Hou Y, Jaffrezic-Renault N, Martelet C, Zhang A, Minic-Vidic J, Gorojankina T, Persuy M-A, Pajot-Augy E, Salesse R, Akimov V (2007) A novel detection strategy for odorant molecules based on controlled bioengineering of rat olfactory receptor I7. Biosensors and Bioelectronics 22 (7):1550-1555. doi.org/10.1016/j.bios.2006.06.018.

8. Marrakchi M, Vidic J, Jaffrezic-Renault N, Martelet C, Pajot-Augy E (2007) A new concept of olfactory biosensor based on interdigitated microelectrodes and immobilized yeasts expressing the human receptor OR17-40. European Biophysics Journal 36 (8):1015-1018. doi.org/10.1007/s00249-007-0187-6.

9. Pennetta C, Akimov V, Alfinito E, Reggiani L, Gorojankina T, Minic J, Pajot Augy E, Persuy MA, Salesse R, Casuso I (2006) Towards the realization of nanobiosensors based on G proteincoupled receptors. hdl.handle.net/11311/561098.

10. Rodriguez Segui S, Pla M, Minic J, Pajot-Augy E, Salesse R, Hou Y, Jaffrezic-Renault N, Mills C, Samitier J, Errachid A (2006) Detection of olfactory receptor I7 self-assembled multilayer formation and immobilization using a quartz crystal microbalance. Analytical letters 39 (8):17351745. doi.org/10.1080/00032710600714030.

11. Vidic J (2010) Bioelectronic noses based on olfactory receptors. Intell Biosens:377-386. doi: $10.5772 / 7163$.

12. Vidic J, Grosclaude J, Monnerie R, Persuy M-A, Badonnel K, Baly C, Caillol M, Briand L, Salesse R, Pajot-Augy E (2008) On a chip demonstration of a functional role for odorant binding 
protein in the preservation of olfactory receptor activity at high odorant concentration. Lab on a Chip 8 (5):678-688. doi: 10.1039/B717724K.

13. Vidic J, Pla-Roca M, Grosclaude J, Persuy M-A, Monnerie R, Caballero D, Errachid A, Hou Y, Jaffrezic-Renault N, Salesse R (2007) Gold surface functionalization and patterning for specific immobilization of olfactory receptors carried by nanosomes. Analytical Chemistry 79 (9):32803290. doi.org/10.1021/ac061774m.

14. Vidic JM, Grosclaude J, Persuy M-A, Aioun J, Salesse R, Pajot-Augy E (2006) Quantitative assessment of olfactory receptors activity in immobilized nanosomes: a novel concept for bioelectronic nose. Lab on a Chip 6 (8):1026-1032. doi: 10.1039/B603189G.

15. Minic J, Persuy MA, Godel E, Aioun J, Connerton I, Salesse R, Pajot-Augy E (2005) Functional expression of olfactory receptors in yeast and development of a bioassay for odorant screening. The FEBS journal 272 (2):524-537. doi.org/10.1111/j.1742-4658.2004.04494.x.

16. Minic J, Sautel M, Salesse R, Pajot-Augy E (2005) Yeast system as a screening tool for pharmacological assessment of g protein coupled receptors. Current medicinal chemistry 12 (8):961-969. doi.org/10.2174/0929867053507261.

17. Akimov V, Alfinito E, Bausells J, Benilova I, Paramo IC, Errachid A, Ferrari G, Fumagalli L, Gomila G, Grosclaude J (2008) Nanobiosensors based on individual olfactory receptors. Analog Integrated Circuits and Signal Processing 57 (3):197-203.

18. Akimov V, Alfinito E, Pennetta C, Reggiani L, Minic J, Gorojankina T, Pajot-Augy E, Salesse R (2006) An impedance network model for the electrical properties of a single-protein nanodevice. In: Nonequilibrium Carrier Dynamics in Semiconductors. Springer, pp 229-232. doi.org/10.1007/s10470-007-9114-0.

19. Benilova I, Chegel VI, Ushenin YV, Vidic J, Soldatkin AP, Martelet C, Pajot E, Jaffrezic-Renault N (2008) Stimulation of human olfactory receptor 17-40 with odorants probed by surface plasmon resonance. European Biophysics Journal 37 (6):807-814. doi.org/10.1007/s00249-008-0272-5.

20. Benilova I, Vidic JM, Pajot-Augy E, Soldatkin A, Martelet C, Jaffrezic-Renault N (2008) Electrochemical study of human olfactory receptor OR 17-40 stimulation by odorants in solution. Materials Science and Engineering: C 28 (5-6):633-639. doi.org/10.1016/j.msec.2007.10.040

21. Hou Y, Helali S, Zhang A, Jaffrezic-Renault N, Martelet C, Minic J, Gorojankina T, Persuy MA, Pajot-Augy E, Salesse R (2006) Immobilization of rhodopsin on a self-assembled multilayer and its specific detection by electrochemical impedance spectroscopy. Biosensors and Bioelectronics 21 (7):1393-1402. doi.org/10.1016/j.bios.2005.06.002.

22. Minic J, Grosclaude J, Aioun J, Persuy M-A, Gorojankina T, Salesse R, Pajot-Augy E, Hou Y, Helali S, Jaffrezic-Renault N (2005) Immobilization of native membrane-bound rhodopsin on biosensor surfaces. Biochimica et Biophysica Acta (BBA)-General Subjects 1724 (3):324-332. doi.org/10.1016/j.bbagen.2005.04.017. 